\title{
Pembiasaan Pengelolaan Sampah sebagai Strategi Pendidikan Karakter Peduli Lingkungan bagi Siswa MI Muhammadiyah Cekel, Karanganyar
}

\begin{abstract}
Hernawan Sulistyanto ${ }^{1}$, Iqna Maulidya Syafira ${ }^{2}$, Amalia Quratul Isnaini ${ }^{3}$, Fitroni Hadi Prasetyo ${ }^{4}$, Wafafi Qolby $^{5}$, Esti Pramita ${ }^{6}$, Retno Aruming Tyas ${ }^{7}$, Indhityas Kurnianing F ${ }^{8}$, Farid Muhammad ${ }^{9}$, Rifki Khusain ${ }^{10}$

${ }_{1,2,3,4,5,6,7,8,9,10}$ Fakultas Keguruan dan Ilmu Pendidikan, Universitas Muhamamdiyah Surakarta, Indonesia
\end{abstract}

\section{INFORMASI ARTIKEL}

Histori Artikel:

Submit: 27 April 2020

Revisi: 2 Mei 2020

Diterima: 4 Mei 2020

Publikasi: 6 Mei 2020

Periode Terbit: Desember 2019

\section{Kata Kunci:}

pendidikan karakter, pengelolaan sampah, lingkungan

\section{Correspondent Author:}

Iqna Maulidya Syafira

Fakultas Keguruan dan Ilmu Pendidikan

Universitas Muhammadiyah Surakarta,

Indonesia

Email:

a410160238@student.ums.ac.id

\begin{abstract}
ABSTRAK
Sampah adalah material sisa yang berasal dari kegiatan sehari-hari manusia yang sudah tidak dapat digunakan. Pengelolaan sampah harus dilakukan dengan baik dan benar sehingga tidak menimbulkan dampakdampak yang dapat merugikan lingkungan sekitar dan dapat merusak ekosistem alam. Tujuan pengamatan ini dilakukan yaitu untuk membiasakan siswa MI Muhammadiyah Cekel dalam pengelolaan sampah, untuk mempermudah dalam pengelompokan sampah saat dibawa ke TPA, dan untuk mengurangi sampah yang dihasilkan di MI Muhammadiyah Cekel. Metode pelaksanaan pada pengabdian ini yaitu: 1) metode ceramah, 2) metode demontrasi, 3) metode tanya jawab, dan 4) pendampingan. Hasil dari pengabdian ini yaitu: 1) Kegiatan sosialisasi, pendampingan, dan pengarahan pengelolaan sampah di MI Muhammadiyah Cekel mendapat respon positif dari peserta didik dan 2) Adanya keberlanjutan yang akan dilakukan sekolah untuk membiasakan mengarahkan peserta didik membuang sampah sesuai dengan jenis tempat sampah dan membiasakan peserta didik membawa piring dan gelas plastik untuk mengurangi produksi sampah plastik di sekolah sebagai pendidikan karakter untuk peserta didik agar mencintai lingkungan dan menerapkan pola hidup sehat.
\end{abstract}

\section{Pendahuluan}

Indonesia merupakan negara yang sering disebut dengan istilah zamrud khatulistiwa. Bermacam-macam tanaman bisa tumbuh dan berkembang subur. Namun, istilah itu sudah tidak sesuai lagi dengan keadaan Indonesia saat ini. Tanah yang gersang dan tandus membuat Indonesia tidak nyaman lagi untuk dihuni. Indonesia juga telah dilanda berbagai macam bencana dari tahun ke tahun, seperti banjir bandang, tanah longsor, tsunami, kekeringan yang sering terjadi setiap tahun. Di wilayah perkotaan banyak sekali cerobongcerobong asap yang ditanam oleh kaum kapitalis yang ingin mengeruk keuntungan tanpa memikirkan dampak yang akan disebabkan terhadap lingkungan sekitar. Polusi air, tanah, dan udara sudah banyak terjadi di 
wilayah perkotaan sehingga masyarakat tidak memiliki tempat untuk bisa bernafas bebas. Limbah rumah tangga dan pabrik makin memperparah kondisi air dan tanah di perkotaan sehingga menimbulkan berbagai jenis penyakit yang mengancam keselamatan manusia di sekitarnya.

Permasalahan-permasalahan itu disebabkan karena ulah manusia yang tidak mau menjaga alam. Mereka melakukan berbagai kegiatan yang merusak alam tanpa pertanggungjawaban, seperti pembakaran hutan, penebangan pohon tanpa reboisasi, dan membuang sampah sembarangan yang mengakibatkan sumber daya alam rusak dan ekosistem alam tidak stabil. Kondisi seperti ini mendapatkan respon yang serius dari masyarakat dunia untuk ikut berpartisipasi dalam menyelamatkan lingkungan melalui berbagai kegaiatan yang berkaitan dengan lingkungan hidup. Para pecinta lingkungan sadar terhadap pentingnya mengambil tindakan demi menyelamatkan bumi dari kehancuran. Hal yang paling kecil untuk menyelamatkan bumi salah satunya yaitu dimulai dari pengelolaan sampah yang baik dan benar.

Sampah adalah material sisa yang berasal dari kegiatan sehari-hari manusia yang sudah tidak dapat digunakan, karena itu harus dikelola. Sampah dapat menimbulkan kerugian jika tidak dikelola dengan baik dan benar. Kerugian yang dapat disebabkan oleh sampah antara lain adalah banjir, meningkatnya pemanasan iklim, menimbulkan bau busuk, mengganggu keindahan, memperburuk sanitasi lingkungan dan ancaman meningkatnya berbagai macam penyakit karena sampah yang tidak dikelola dengan baik dan benar.
Sampah tidak dapat dilepaskan dari kehidupan manusia sehari-hari, dimana ada manusia pasti ada sampah, karena sampah merupakan sisa-sisa kegiatan manusia dalam kehdiupan sehari-hari. Meningkatnya jumlah penduduk menyebabkan bertambahnya jumlah sampah yang dihasilkan dari setiap penduduk. Sampah akan menjadi masalah besar apabila tidak dikelola dengan baik, karena sampah mempengaruhi kesehatan masyarakat dan kebersihan serta keindahan lingkungan.

Kerusakan ekosistem salah satunya disebabkan oleh sampah, maka dari itu saat ini pemerintah memberikan perhatian serius terhadap sampah. Tetapi masih banyak tantangan untuk dapat mencapai target yang diinginkan oleh pemerintah Indonesia dimana Indonesia merupakan negara yang sedang berkembang dan memiliki karakteristik masyarakat yang majemuk sehingga kondisi tersebut dapat mengakibatkan banyak sekali masalah yang muncul dan belum terselesaikan dengan baik terutama dalam hal pengelolaan sampah.

Pengelolaan sampah yang baik harus melibatkan partisipasi masyarakat, maka dari itu perlu pengenalan sejak dini dalam pengelolaan sampah sehingga pada saat dewasa sudah memahami manfaat dari pengelolaan sampah. Pengelolaan sampah memiliki maksud untuk meningkatkan kesehatan masyarakat dan kualitas lingkungan. Pengelolaan sampah dari sudut pandang kesehatan lingkungan dipandang sangat baik jika sampah tersebut tidak menjadi sumber penyebaran virus penyakit. Syarat lain yang harus dipenuhi yaitu tidak mencemari udara, air, dan tanah, tidak mengakibatkan bau, dan tidak menyebabkan dampak buruk lainnya. 
Isu tentang lingkungan hidup seperti halnya sampah merupakan salah satu perhatian utama di Idunia internasional saat ini. Hal ini dipicu oleh perilaku manusia yang kurang peduli pada lingkungannya yang menyebabkan kondisi lingkungan alam semakin hari semakin memprihatinkan. Menurut Wiyani (2012:4) "Salah satu upaya untuk perbaikan kualitas sumber daya manusia adalah munculnya gagasan pendidikan karakter dalam dunia pendidikan di Indonesia". Pendidikan karakter untuk menjaga lingkungan hidup haruslah menyentuh kepada usia dini. Lembagalembaga pendidikan pengajaran yang langsung membangun pola pikir peserta didik untuk dapat menjaga lingkungan.

Lembaga pendidikan merupakan benteng yang sangat tangguh untuk menanamkan nilainilai cinta lingkungan hidup kepada anak-anak bangsa. Hal ini berguna untuk menyelamatkan lingkungan alam, para pendidik harus mengajarkan kepada anak-anak tentang pentingnya mencintai dan merawat lingkungan hidup. Pendidik tidak hanya memberikan ilmu saja, tetapi memberika contoh aksi nyata, misalnya membuang sampah pada tempatnya, tidak menyisakan makanan, mengelompokkan sampah organik dan anorganik, serta melakukan sosialisasi lingkungan bersih kepada masyarakat. Hal tersebut dilakukan agar masyarakat sekitar sadar terhadap persoalan lingkungan hidup dan memelihara lingkungan sekitarnya.

Penanaman karakter bangsa yang secara sistematis bisa dilakukan dengan baik, salah satunya adalah melalui pendidikan karakter, khususnya pada nilai peduli lingkungan. Pendidikan karakter harus berkelanjutan dan tidak pernah berakhir, sebagai bagian terpadu untuk menyiapkan generasi bangsa, yang disesuaikan dengan sosok manusia masa depan, berakar pada filosofi dan nilai kultural religius bangsa Indonesia (Narimo, et al, 2018).

Pendidikan menurut Mulyasa (2011) merupakan upaya untuk membantu perkembangan jiwa anak-anak lahir maupun batin, dari sifat kodratnya menuju kearah peradaban yang manusiawi dan lebih baik sementara itu, karakter adalah kualitas individu atau kolektif yang menjadi ciri seseorang atau kelompok. Pendidikan karakter merupakan pendidikan yang menanamkan dan mengembangkan karakter-karakter luhur kepada peserta didik, sehingga mereka memiliki karakter luhur, menerapkan dan mempraktikan dalam kehidupannya, entah dalam keluarga, sebagai anggota masyarakat dan warga negara. (Wibowo, 2013)

Pendidikan karakter adalah proses pemberian tuntunan kepada peserta didik untuk menjadi manusia seutuhnya yang berkarakter dalam dimensi hati, pikir, raga, serta rasa dan karsa. Pendidikan karakter juga dapat dimaknai sebagai upaya yang terencana untuk menjadikan peserta didik mengenal, peduli, dan menginternalisasi nilai-nilai sehingga peserta didik berperilaku sebagai insan kamil. (Samani \& Hariyanto, 2012).

Pendidikan karakter membentuk kepribadian seseorang melalui pendidikan budi pekerti, yang hasilnya terlihat dalam tindakan nyata seseorang seperti tingkah laku yang baik, peduli lingkungan, jujur, bertanggung jawab, menghormati hak orang lain, kerja keras dan sebagainya (Gunawan, 2012).

Guru memiliki peran penting untuk membentuk dan menanamkan karakter cinta 
lingkngan kepada anak-anak. Sejak dini anakanak disadarkan bahwa setiap orang memiliki tanggungjawab untuk melestarikan lingkungan hidup. Terdapat beberapa cara yang dapat dilakukan untuk melestarikan lingkungan hidup, salah satunya yaitu pengelolaan sampah dengan memisahkan kelompok sampah organik dan anorganik.

Merujuk pada program pemisahan jenis sampah untuk pendidikan karkater siswa MI Muhammadiyah Cekel, sekolah dan mahasiswa KKN Dik menyediakan dan memfasilitasi beberapa tempat sampah khusus untuk organik dan anorganik. Dengan demikian diharapkan siswa dapat membiasakan memisahkan sampah sesuai dengan jenis sampah tersebut, sehingga memudahkan dalam pembuangannya di TPA.

Fadillah dan Khorida (2013) Pendidikan Karakter Anak Usia Dini mengungkapkan bahwa melalui pendidikan karakter anak usia dini diharapkan dapat mampu membangkitkan dan mewujudkan kepedulian lingkungan. Pembelajarannya dapat dilakukan dengan mengajarkan anak untuk membuang sampah pada tempatnya, menyayangi tumbuhtumbuhan, dan selalu menjaga kebersihan di tempat manapun berada.

Melalui kegiatan pembiasaan pengelolaan sampah di MI Muhammadiyah Cekel, menurut penulis menarik untuk diteliti dan dikembangkan sebagai cara alternatif memberikan pemahaman pada masyarakat terhadap masalah lingkungan. Untuk itulah penulis termotivasi untuk melakukan pengamatan tentang "Pembiasaan Pengelolaan Sampah Sebagai Strategi Pendidikan Karakter Peduli Lingkungan Siswa MI Muhammadiyah Cekel". Tujuan pengamatan ini dilakukan yaitu untuk membiasakan siswa MI Muhammadiyah
Cekel dalam pengelolaan sampah, untuk mempermudah dalam pengelompokkan sampah saat dibawa ke TPA, dan untuk mengurangi sampah yang dihasilkan di MI Muhammadiyah Cekel.

\section{Metode Pelaksanaan}

Pelaksanaan kegiatan Kuliah Kerja Nyata Pendidikan (KKN Dik) di MI Muhammadiyah Cekel telah dilakukan pada hari Rabu tanggal 23 Januari 2020 sampai dengan selesai. MI Muhammadiyah Cekel terdiri dari 11 kelas dengan jumlah siswa 305 siswa. Masing-masing tingkatan kelas berjumlah 2 rombel, kecuali kelas 6 hanya terdapat 1 rombel.

Metode pelaksanaan yang dilakukan adalah dengan memberikan pendampingan yang ditujukan kepada peserta didik MI Muhammadiyah Cekel dari kelas 1 sampai dengan kelas 6. Adanya pendampingan ini diharapkan bahwa peserta didik mampu memilah sampah sesuai dengan jenisnya sejak dini. Proses pelaksanaan dimulai dengan melakukan observasi terlebih dahulu untuk mengetahui bagaimana kebiasaan peserta didik membuang sampah pada tempatnya secara benar atau tidak, kemudian dilihat kembali apakah membuang di tempat sampahnya dicampur atau dipisah. Berdasarkan hasil observasi ini maka dapat diketahui kebiasaan peserta didik setiap harinya pada saat membuang sampah sisa makanan atau jajanan di sekolah.

$$
\text { Pengelolaan sampah di MI }
$$
Muhammadiyah ini sebelum dilakukan kegiatan Kuliah Kerja Nyata Pendidikan (KKN Dik) dilakukan oleh petugas kebersihan sekolah. Tempat sampah sudah disediakan terpisah antara sampah organik dan anorganik, 
karena kurangnya pemahaman dan pengawasan guru sehingga peserta didik masih membuang sampah tidak sesuai dengan jenis sampah tersebut. Dengan adanya kegiatan KKN Dik di MI Muhammadiyah Cekel diharapkan peserta didik mampu merubah paradigma kebiasaan anak SD untuk membuang sampah sesuai tempatnya.

Adapun metode yang dilakukan yang terkait dalam kegiatan ini meliputi:

1. Metode ceramah. Metode ini digunakan pada saat sosialisasi pembiasaan hidup sehat tentang pengelolaan sampah.

2. Metode demonstrasi. Metode ini digunakan pada saat penyampaian materi yaitu: pengertian sampah, jenis-jenis sampah, dampak membuang sampah sembarangan, cara pengelolaan sampah yang baik dan benar, dan peragaan drama tentan pengelolaan sampah.

3. Metode tanya jawab. Metode ini digunakan untuk mengingatkan kembali pada peserta didik terkait materi yang telah disampaikan oleh Tim sehingga peserta didik merasa mendapat banyak pengetahuan baru, pengalaman, dan manfaat yang dapat diimplementasikan kepada keluarga.

4. Pendampingan. Kegiatan ini dilakukan untuk memberikan pendampingan dan pengarahan pada peserta didik agar mereka mampu membiasakan diri membuang sampah sesuai dengan jenisnya.

\section{Hasil Pelaksanaan dan Pembahasan}

Adapun untuk hasil kegiatan KKN Dik adalah sebagai berikut: melakukan diskusi dengan guru untuk mendapat informasi terkait pengelolaan sampah yang sudah ada apakah sudah terpisah atau belum, dan masalah apa yang dihadapi dalam mengelola sampah agar pada diskusi ini mampu memberikan pemahaman yang sama dalam mengelola sampah dengan benar dan baik pada anak usia dini. Berdasarkan hasil diskusi tersebut dari tim KKN Dik kemudian melakukan sosilaisasi, pendampingan, dan pengarahan kepada peserta didik MI Muhammadiyah Cekel kelas 1 sampai kelas 6 dengan menyediakan dua tempat sampah yang terdiri dari tempat sampah untuk jenis organik dan tempat sampah untuk jenis anorganik. Selain itu tim KKN Dik juga menghimbau siswa untuk membawa piring dari gelas plastik untuk jajan di sekolah sehingga dapat mengurangi sampah plastik.

Saat kegiatan sosialisasi, pendampingan, dan pengarahan maka tim memberikan penjelasan terlebih dahulu tentang pengertian sampah, jenis-jenis sampah, dampak membuang sampah sembarangan, dan pengelolaan sampah yang memenuhi syarat kesehatan.

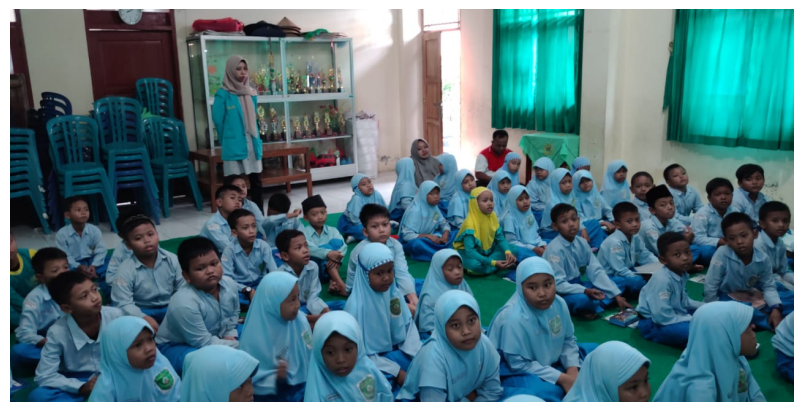

Gambar 1. Sosialisasi tentang Pengelolaan Sampah

Setelah diberi penjelasan kemudian peserta didik MI Muhammadiyah Cekel dari kelas 1 sampai kelas 6 melakukan demonstrasi dengan membuang sampah secara benar sesuai dengan dua jenis tempat sampah yang sudah tersedia, dan apabila peserta didik melakukan kesalahan dalam membuang sampah yang tidak 
sesuai tempatnya maka dari tim KKN Dik mengingatkan dan menjelaskan kembali untuk membuang sampah sesuai dengan tempat dan jenis sampahnya. Jika peserta didik tetap mengulang-ulang kesalahan tersebut maka tim KKN Dik memberikan sanksi untuk menghafalkan surat-surat pendek. Selain melakukan pengawasan terkait membuang sampah sesuai dengan jenisnya, tim KKN Dik juga menghimbau peserta didik agar membeli jajan saat istirahat menggunakan piring dan gelas plastik yang sudah mereka bawa dari rumah. Setelah piring selesai digunakan peserta didik dibiasakan mencucinya di tempat cuci piring yang sudah di sediakan oleh sekolah. Hal ini dilakukan untuk mengurangi produksi sampah plastik di MI Muhammadiyah Cekel.

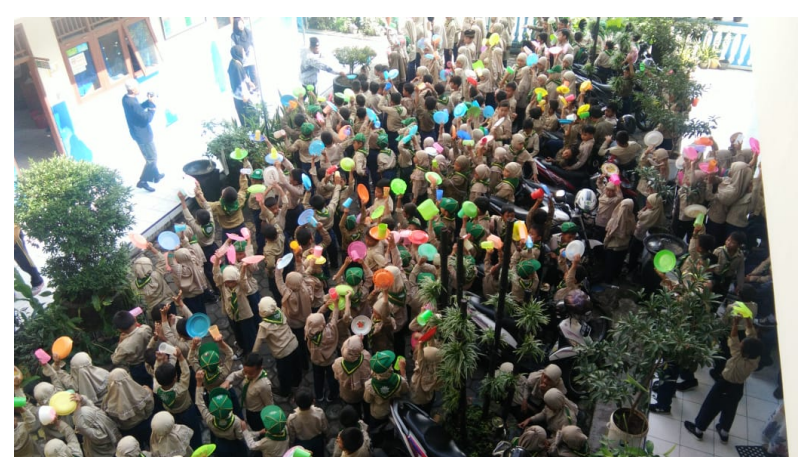

Gambar 2. Pembiasaan Siswa Membawa Piring untuk Jajan di Sekolah

Pendampingan yang dilakukan selama 1,5 bulan memeberikan dampak positif bagi peserta didik MI Muhammadiyah Cekel. Diadakannya pendampingan ini membuat peserta didik terbiasa membuang sampah sesuai dengan jenis tempat sampahnya. Selain itu kegiatan ini juga membantu mengurangi sampah plastik yang di hasilkan oleh MI Muhammadiyah Cekel. Pembiasaan yang dilakukan ini dapat dijadikan pendidikan karakter untuk peserta didik sehingga mereka lebih mencintai lingkungan dan menerapkan pola hidup sehat.

Tempat pembuangan sampah yang tersedia memiliki kondisi yang layak serta jumlah penampungan yang cukup untuk menampung sampah yang dihasilkan warga sekolah, sehingga sekolah terlihat cukup bersih. Secara kognitif pemahaman siswa tentang manfaat dan kegunaan tempat pembuangan sampah sudah cukup baik. Secara afektif, kepedulian siswa akan keberadaan pembuangan sampah sudah terlihat. Secara psikomotorik siswa menunjukkan sikap positif dalam merawat tempat pembuangan sampah di sekitar kelasnya.

Hasil kegiatan ini sesuai dengan yang pernah dilakukan oleh Hansen dan Ratna (2019) menyatakan bahwa penyuluhan dan pendampingan terkait membuang sampah sesuai dengan jenisnnya mendapat respon yang positif dari peserta didik. Mereka sangat antusias dalam mengikuti kegiatan sehingga kegiatan berjalan dengan lancar. Setelah kegiatan ini juga sekolah sudah menempatkan sampah di tempat yang terpisah.

Mulyati, dkk (2019) meyimpulan bahwa mereka telah membentuk sebuah kegiatan Bank Sampah "Mulia Sejahtera" dan lengkap dengan pengurusnya. Bank Sampah Mulia Sejahtera akan beroperasi setiap hari minggu dengan jam operasional yang ditentukan oleh pengurus. Bank sampah yang telah dibentuk diupayakan supaya dapat terus kontinyu dan berkesinambungan. Selanjutnya kegiatan akan diikuti dengan penataan dan pemilahan sampah. Pada kesempatan berikutnya akan ditindaklanjuti dengan pelatihan lanjutan terkait dengan bank sampah misalnya pengelolaan sampah, pelatihan pembuatan 
barang-barang kerajinan terbuat dari sampah, pembuatan kompos, dll.

\section{Simpulan}

Berdasarkan hasil pelaksanaan kegiatan KKN Dik ini dapat disimpulkan sebagai berikut, Kegiatan sosialisasi, pendampingan, dan pengarahan pengelolaan sampah di MI Muhammadiyah Cekel mendapat respon positif dari peserta didik, Adanya keberlanjutan yang akan dilakukan sekolah untuk membiasakan mengarahkan peserta didik membuang sampah sesuai dengan jenis tempat sampah dan membiasakan peserta didik membawa piring dan gelas plastik untuk mengurangi produksi sampah plastik di sekolah sebagai pendidikan karakter untuk peserta didik agar mencintai lingkungan dan menerapkan pola hidup sehat.

Saran-saran yang dapat diberikan untuk pelaksanaan kegiatan ini adalah kegiatan semacam ini dapat dilakukan di sekolahsekolah lain dengan pengembangan metodemetode yang lebih menarik dan inovatif sebagai pendidikan karakter peserta didik untuk mencitai lingkungan dan menerapkan pola hidup sehat.

\section{Daftar Pustaka}

Fadillah, Muhammad dan Lilif Mualifatu Khorida. 2013. Pendidikan Karakter Anak Usia Dini. Jogjakarta: Ar-Ruzz Media.

Gunawan Heri. 2012. Pendidikan Karakter Konsep dan Implementasi. Bandung: Alfabeta.

Hansen, \& Yuliawati, R. (2019). Pendidikan Kesehatan Pengelolaan Sampah Sejak Usia Dini di SDN 015 Samarinda Ulu. Jurnal Pengabdian Kepada Masyarakt, 10(2), 234-238.

Jana, I W., Mardani, N. K., \& Suyasa, I W. B. (2006). Analisis Kaotrakteristik Sampah dan Limbah Cair Pasar Badung dalam Upaya Pemilihan Sistem Pengelolaannya. Ecotrophic, 1(2), 1-10.

Kurniaty, Y., dkk. (2016). Mengefektifkan Pemisahan Jenis Sampah Sebagai Upaya Pengelolaan Sampah Terpadu di Kota Magelang. Varia Justicia, 12(1), 135-150.

Mulyasa. 2011. Menejemen Pendidikan Karakter. Jakarta: PT Bumi Angkasa.

Mulyati, S., dkk. (2019). Pendampingan Pembentukan Bank Sampah di Kelurahan Meteseh Kecamatan Tembalang Semarang. Jurnal Link, 15(1), 23-26. http://ejournal.poltekkessmg.ac.id/ojs/10.31983/link.v15i1.4109.

Narimo, S., Maryadi, M., Fatoni, A., Anif, S., Sumardjoko, B., \& Adhantoro, M. S. (2018, November). Pancasila and Citizens Education (PKn) Learning Based on Local Culture in The Establishment of Student Characters. In Profunedu International Conference Proceeding (Vol. 1, pp. 255-260).

Samani, Muchlas dan Hariyanto. 2012. Konsep dan Model Pendidikan Karakter. Bandung: PT Remaja Rosdakarya.

Wibowo, Agus. 2013. Menejemen Pendidikan Karakter di Sekolah. Yogyakarta: Pustaka Pelajar.

Windraswara, R., \& Prihastuti, D. A. B. (2017). Analisis Potensi Reduksi Sampah Rumah Tangga Untuk Peningkatan Kualitas Kesehatan Lingkungan. Unnes Journal of Public Health, 6(2), 123-130.

Wiyani, Novan Ardy. (2012). Manajemen Pendidikan Karakter: Konsep dan Implementasinya di Sekolah. Yogyakarta: PT Pustaka Insan Madani.

Yahya, M. S. (2019). Integrasi Pendidikan Karakter Peduli Lingkungan dalam Kegiatan Pembelajaran di SDIT Imam Syafi'i Petanahan Kebumen. Insania, 24(2), 232-246.

Yudistirani, S. A., Syaufina, L., \& Mulatsih, S. (2015). Desain Sistem Pengelolaan 
doi: 10.23917/bkkndik.v1i2.10768

Sampah Melalui Pemilahan Sampah

Organik dan Anorganik Berdasarkan
Persepsi Ibu-Ibu Rumah Tangga.

Konversi, 4(2), 29-42. 